IRSH 53 (2008), Supplement, pp. 45-7I doi:I0.10I7/S002085900800360X (C) 2008 Internationaal Instituut voor Sociale Geschiedenis

\title{
The Political Economy of European Craft Guilds: Power Relations and Economic Strategies of Merchants and Master Artisans in the Medieval and Early Modern Textile Industries
}

\author{
Hug O S OLY
}

In a wealth of studies written from the nineteenth century onward, researchers have reviewed political and legal aspects of European craft guilds in the Middle Ages and the early modern period. In addition to historians, these researchers include political scientists and legal scholars, ${ }^{\mathrm{I}}$ and their interest remains strong to this day. This is understandable, since however much views may differ as to the significance of these institutions, there is no doubt that their origin, evolution, and abandonment were deeply influenced by political events.

While a vast body of literature has been and continues to be written about their interactions with local and supralocal authorities, their constitutional positions, and their charters, studies that transcend national or even regional contexts are few and far between, thus leaving many questions unanswered. On the other hand, the economic role that craft guilds played in pre-industrial Europe has instigated debates since the eighteenth century - and in some cases even earlier - that became far more heated in the course of the nineteenth century, due in part to the highly divergent views of contemporary developments, especially the rise of industrial capitalism and what was known as "the social problem". ${ }^{2}$ This approach has always revolved around the question of whether craft guilds benefited the economy of pre-industrial Europe, or whether corporative organizations complicated or even prevented adaptations to changes in market demand or technological progress. Most authors have long regarded craft guilds as obstacles to structural economic changes, at least during the

I. See especially Otto Gerhard Oexle, "Die mittelalterliche Zunft als Forschungsproblem", Blätter für deutsche Landesgeschichte, i 8 (1982), pp. I-44; Cesare Mozzarelli (ed.), Economia e corporazioni: il governo degli interessi nella storia dell'Italia dal medioevo all'età contemporanea (Milan, I988); Virginia R. Bainbridge, Guilds in the Medieval Countryside: Social and Religious Change in Cambridgeshire c.1350-I558 (Woodbridge, I996), pp. I-2 I. 2. Heinz-Gerhard Haupt, "Guild Theory and Guild Organization in France and Germany during the Nineteenth Century", in Mark Bevir and Frank Trentmann (eds), Markets in Historical Contexts: Ideas and Politics in the Modern World (Cambridge, 2005), pp. 90-104. 
early modern period. ${ }^{3}$ Since the I990s, however, they have argued increasingly that craft guilds are more likely to have benefited the economy. ${ }^{4} \mathrm{But}$ this revisionist thesis is not generally accepted. Some historians reject it, emphasizing that craft guilds were far from efficient institutional arrangements operating to the advantage of the pre-industrial economy. ${ }^{5}$

European craft guilds existed in many different forms and performed myriad functions, often simultaneously serving multiple objectives that might vary greatly over time as well. This would suggest that no single element should be considered in isolation. Still, the political economy of craft guilds has received little consideration thus far, particularly regarding the issue of whether these institutions promoted or impeded economic activity. Few authors have analysed the articulation of politico-institutional and socio-economic changes, even though such an approach is essential for examining the extent to which members of corporative organizations were in a position to meet new challenges (i.e. to launch entrepreneurial initiatives).

The aim of this essay is to shed light on how power relationships on the one hand and economic strategies of merchants and master artisans on the other related to one another, with due consideration being given to Derek Keene's advice that it is better "to focus on the nature of the power that was articulated through the different forms of association, which can be described as guilds than on the institution itself". ${ }^{6}$ A comparative approach is necessary

3. Many historians have endorsed the views of Henri Pirenne, Histoire de Belgique, II, Du commencement du XIVe siècle à la mort de Charles le Téméraire (Brussels, I922), pp. 436-438, and IV, La révolution politique et religieuse (Brussels, I919), p. 427. See the interesting remarks of Walter Prevenier, "Henri Pirenne et les villes des anciens Pays-Bas au bas Moyen Age (XIVe-XVe siècles)", in La fortune historiographique des thèses d'Henri Pirenne. Actes $d u$ Colloque organisé à l'occasion du cinquantenaire de la mort de l'historien belge par l'Institut des Hautes Etudes de Belgique (Archives et Bibliothèques de Belgique, special issue 28) (Brussels, I986), pp. 48-49.

4. See inter alia James R. Farr, "On the Shop Floor: Guilds, Artisans, and the European Market Economy, I350-1750", Journal of Early Modern History, I (1997), pp. 24-54; Josef Ehmer, "Traditionelles Denken und neue Fragestellungen zur Geschichte von Handwerk und Zunft", in Friedrich Lenger (ed.), Handwerk, Hausindustrie und die historische Schule der Nationalökonomie. Wissenschafts- und gewerbegeschichtliche Perspektiven (Bielefeld, 1998), pp. I9-77; S.R. Epstein, "Craft Guilds, Apprenticeship, and Technological Change in Preindustrial Europe", The Journal of Economic History, 58 (1998), pp. 684-71 3; idem et al. (eds), Guilds, Economy and Society (Madrid, 1998); Reinhold Reith, "Technische Innovation im Handwerk der frühen Neuzeit? Traditionen, Probleme und Perspektiven der Forschung”, in Karl Heinrich Kaufhold and Wilfried Reininghaus (eds), Stadt und Handwerk in Mittelalter und Früher Neuzeit (Cologne, 2000), pp. 2 I-60; Heinz-Gerhard Haupt (ed.), Das Ende der Zünfte. Ein europäischer Vergleich (Göttingen, 2002).

5. For a critique of the rehabilitation thesis, see Sheilagh Ogilvie, "Guilds, Efficiency, and Social Capital: Evidence from German Proto-Industry”, Economic History Review, 57 (2004), pp. 286-333. 6. Derek Keene, "Guilds in English Towns, AD 1000-1 500", in Brian H.A. Ranson (ed.), Guild-hall and Government: An Exploration of Power, Control and Resistance in Britain and China, II: Power, Resistance and Authorities: Aspects of Guild Organization in England (Hong Kong, 1997), p. 43. 
to ascertain which power constellation determined whether individual master artisans generally had ample, little, or no economic leeway under the existing legislation. Given the central question in debates about the economic significance of craft guilds, sectors that produced for export seem to be the most relevant. The predominant export-oriented industry with respect to capital investment, employment, and profits was textile manufacturing, where several stages of production became guild-based very early on in many parts of western Europe.?

\section{POWER RELATIONS AND ECONOMIC STRATEGIES}

Authors writing about medieval and early modern textile trades have examined at length whether merchant entrepreneurs coordinated the production process or at least controlled certain stages of it, especially in weaving. Until well into the twentieth century, the prevailing view was that merchant entrepreneurs in many cities and rural areas where textiles were produced used the putting-out system (Verlag in German) to achieve economic control. This informal organizational structure fitted perfectly within the logic of merchant capital, offering the great advantage of decentralization and thus minimal fixed-capital requirements, without the drawback of large numbers of small producers taking uncoordinated decisions. Since the I970s, however, additional empirical material keeps demonstrating that the situation was more complicated, and that master artisans evolved as true entrepreneurs in the urban textile trades in several regions from the late Middle Ages onward. ${ }^{8}$ Their success in this respect was greatest in places where the regulations enabled them to increase their production - and in some cases raise their productivity levels as well through subcontracting, which entailed delegating productive or organizational tasks to other master artisans.

Since workshop size was restricted at nearly all times and places, forming or expanding subcontracting networks was the most obvious way for the more affluent master artisans to meet increases in demand for manufactured goods. This system enabled them to avoid additional fixed-capital investments and to pass most of the risks on to the subcontractors while nonetheless realizing economies of scale that reduced their transaction costs and offered other advantages as well. Scale expansion was at any rate a sine qua non for master artisans to engage in supralocal commercial activities, which in turn considerably broadened their opportunities to accumulate capital. This was contingent, however, on guild members in export-oriented trades being

7. I.e. west of the Elbe.

8. See especially Rudolf Holbach, Frühformen von Verlag und Grossbetrieb in der gewerblichen Produktion, I3-I6 Jahrbundert [Vierteljahrschrift für Sozial- und Wirtschaftsgeschichte, Beiheft no. I Io] (Stuttgart, I994), pp. 205-208. 
authorized to trade, if they were in a position to engage in subcontracting, and this situation could not be taken for granted.'

Where in Europe west of the Elbe could large master artisans producing textiles apply subcontracting and market their own manufactured goods, and why could they do so in some cities and regions but not in others? A comprehensive account of all geographical variations is impossible to provide for lack of sufficient empirical data. Indications are available only for specific cities and regions, but these at any rate enable us to identify similarities and differences between areas with high concentrations of craft guilds: northern Italy, the Low Countries, central Europe, England, and France. In addition, they enable us to relate variations in socioeconomic positions to divergent constellations of political power that emerged in the late Middle Ages. This is absolutely essential, since the answer to the second crucial question lies within the politico-institutional context.

Craft guilds are often described as "powerful" or "weak", based primarily on their measure of political influence, ranging from participation in the local administration to the absence of the right to file petitions, in conjunction with the extent to which the members of these organizations could regulate the occupation; powerful guilds might penalize those who violated the regulations. As for guild-based export trades, the additional question is: cui bono? Were powerful craft guilds run by true master artisans? Or did the members of these organizations also include merchants, and did their will prevail? This point is essential for understanding why craft guilds did or did not respond adequately - from a global economic perspective - to changing circumstances, or, in other words, whether or not they were "efficient institutions" and why. The example of guildbased Italian textile trades illustrates this point.

\section{NORTHERN ITALY: POWERFUL MERCHANT ENTREPRENEURS}

Guilds and confraternities arose in northern Italy from the early twelfth century onward, coinciding with the spectacular urban and commercial growth in this region. Merchants, justices, and notaries were generally the first to form associations, followed by shopkeepers and master artisans. By I 300 all large and medium-sized cities abounded with professional associations, ${ }^{10}$ which protected the interests of the matriculated members

9. For more detail, see Catharina Lis and Hugo Soly, "Subcontracting in Guild-Based Export Trades, Thirteenth-Eighteenth Centuries", in S.R. Epstein and Maarten Prak (eds), Guilds, Innovation and the European Economy, I400-I 800 (Cambridge, 2008).

ı. See Luca Mocarelli, "The Guilds Reappraised: Italy in the Early Modern Period", in this volume, pp. I59-178. 
through legislation, jurisdiction, and mutual funds. Around that time, formal guilds had a say in politics nearly everywhere, and often a decisive one. The thirteenth century was indeed the era of the popolo, the movement that started to resemble a political revolution in a great many cities and boroughs around I 250 and ultimately broadened the local councils. As a result, the guilds were able to act as lobbies. In Florence, the main production centre of woollen cloth, a guild-based system materialized. Rather than the guilds with the largest membership, however, the most affluent and most powerful arti were in charge: the associations of cloth merchants and cloth finishers, of moneychangers, and of justices and notaries (calimala, cambio, and gindici e notai).

Within each of these corporative organizations, a very small group controlled the arte and determined electoral policy. Even during the most "democratic" stage in the history of thirteenth-century Florence, a merchant elite remained in control. The Ciompi Revolt of $\mathrm{I} 378$ brought no changes in the highly inequitable balance of power, neither on the city council, nor within the guilds. Among both the calimala and the arte della lana, the association of weavers and other (male) woolworkers, affluent merchant entrepreneurs continued to dominate direct producers. ${ }^{\text {II }}$ These producers were unable to launch economic initiatives. They could do so neither collectively, for lack of effective political clout, nor individually, because of their minimal capital; the catasto of 1427 reveals that over half the master weavers did not even own a loom. ${ }^{12}$ The Florentine textile industry therefore remained subject to the logic of commercial capital. The same held true for the other cities and towns in northern Italy where export-oriented trades emerged in the thirteenth century. In several textile centres the municipal councils became guild-based, just as in Florence. Even where this was not the case, the guilds at least participated in political decision-making. In practice, however, nothing changed for the masses of lavoranti involved in cloth-making: they had no part in the exercise of power; the mercatores, on whom most weavers were economically dependent, reaped the benefits of the "popular revolution". ${ }^{13}$

Urban silk weavers in Italy never managed to negotiate any political say or even to influence local policy. Wherever they organized and had their

I I. See especially John Najemy, Corporatism and Consensus in Florentine Electoral Politics, I280-I400 (Chapel Hill, NC, I982), and Samuel Cohn, The Laboring Classes in Renaissance Florence (New York [etc.], I980).

I2. Bruno Dini, "I lavoratori dell'arte della lana a Firenze nel XIV e XV secolo", in Artigiani $e$ salariati. Il mondo del lavoro nell'Italia dei secoli XII-XV (Pistoia, 1984), pp. 27-68; Alessandro Stella, "La bottega e $i$ lavoranti: approche des conditions de travail des Ciompi", Annales ESC, 44 (1989), pp. 529-551, and idem, La révolte des Ciompi. Les hommes, les lieux, le travail (Paris, 1993), pp. 99-123.

13. Philip Jones, The Italian City-State: From Commune to Signoria (Oxford, 1997), pp. 228-23I, 249, 50I-502, 505-507, 516-517, 588-589 (with references to the literature). 
guilds recognized by the authorities, they lost out to the powerful guilds of the silk merchants, including the setaioli, the merchant entrepreneurs who coordinated the activities of a great many producers by means of the puttingout system. The setaioli used their political influence to convince city councils to include all kinds of prohibitions in the charters of the silk weavers' guilds. In the fourteenth and fifteenth centuries they wielded almost total control over the silk weavers. Henceforth, in most branches of the silk industry the latter could work only for a setaiolo or merchant entrepreneur, who paid them piece rates. In some towns master weavers retained the right to manufacture fabrics independently for market sale, but this right was limited to one or two looms that the master himself and his family had to operate, without the assistance of journeymen or apprentices; the output of all the other looms was reserved for the commissions provided by the setaiolo. ${ }^{14}$ Such restrictions obviously prevented the master artisans affected from accumulating capital and engaging in entrepreneurial initiatives.

The absolute preponderance of merchant capital proved to have severe consequences when the Italian textile trades encountered rising international competition during the seventeenth and eighteenth centuries. Most merchants continued to regard trade profits as their top priority and were disinclined to introduce new production processes, which required fixedcapital investments. During the second half of the seventeenth century, the setaioli shifted their focus to the preparatory production stages. As a result, France gradually became the new centre of silk weaving. The master silk weavers were unable to turn the tide, as they lacked autonomy in manufacturing. In some centres they were not even entitled to work independently, and in others this right was so heavily restricted that weavers were unable to operate as entrepreneurs.

In the eighteenth century, silk dyers' guilds tried to introduce new production processes but were blocked by the merchants. This happened in Venice, for example, where the silk merchants' guild thwarted the effort of the master silk dyers to set up a centralized firm where all producers could use a new technology. The silk merchants feared that master artisans might become serious competitors upon gaining control of an important stage in the production process, and they were sufficiently influential to convince the authorities to reject the proposal. ${ }^{\mathrm{IS}}$ Matters were hardly any different in cities that were more industrial than the merchant city of Venice. During the second half of the seventeenth century, when foreign master artisans in Milan and Padua offered to introduce knitting frames "in the

I4. Paola Massa Piergiovanni, "Technological Typologies and Economic Organisation of Silk Workers in Italy, from the XIV th to the XVIIIth Centuries", The Journal of European Economic History, 22 (1993), pp. 543-564; Luca Molà, The Silk Industry of Renaissance Venice (Baltimore, $\mathrm{MD}$, [etc.], 2000), pp. xiv-xv.

I 5. Piergiovanni, “Technological Typologies”, pp. 557-560. 
English fashion" there, they met with fierce resistance from the merchants' guilds, as their members coordinated the manufacture of silk and woollen stockings by means of the putting-out system. The merchant entrepreneurs concerned were aware that such new technology might well give rise to a strong organization of skilled artisan entrepreneurs - a group of industrial capitalists - and advised the municipal authorities to reject the offer, which they did. In mid eighteenth-century Milan, the merchants' guild quashed a proposal to innovate the manufacture of cotton cloth for similar reasons, even though the artisans' guilds expressed no objections whatsoever to such innovation. ${ }^{16}$

The example of the guild-based Italian textile trades demonstrates that the guilds were not automatically to blame for their decline, as some historians have argued. ${ }^{17}$ Shedding light on the economic leverage of master artisans requires considering the balances of power that materialized from the thirteenth century (and in some cases even earlier), giving merchants a particularly strong say in all decisions relating to the manufacture of export goods, whether they were organizational ones or concerned the introduction of new technologies or products. It might appear strange that in cities where export-oriented craft guilds had political power, the charters of these organizations tended to be inclusive rather than exclusive. ${ }^{18}$ Note, however, that merchants were the ones in control, and that they had good reason not to want guilds to be able to deny anybody access to the craft. After all, the more open a guild was, the more members it would be able to recruit, thereby making it easier for merchant entrepreneurs to impose their terms. The possibility of joining multiple guilds was also to the advantage of the merchants. In the first half of the eighteenth century in Turin, for example, several merchants joined the tailors' guild, as such membership enabled them to circumvent all kinds of restrictions on their commercial undertakings. ${ }^{19}$ The preponderance of commercial capital is also apparent from

16. Carlo Marco Belfanti, "Guilds, Patents, and the Circulation of Technical Knowledge: Northern Italy during the Early Modern Age", Technology and Culture, 45 (2004), p. 579 (with references to the literature).

17. See especially Carlo M. Cipolla, "The Decline of Italy: The Case of a Fully Matured Economy", Economic History Review, 5 (1952), pp. 178-187, and idem, Before the Industrial Revolution: European Society and Economy, I000-I700 (London, 1993), pp. 243, 247. Recent research has revived the question of the guilds' economic utility in early modern Italy: Alberto Guenzi, Paolo Massa, and F. Piola Caselli (eds), Guilds, Markets and Work Regulations in Italy, I6th-19th Centuries (Aldershot, 1998). See also the critical comments of Christopher F. Black, Early Modern Italy: A Social History (London [etc.], 200I), pp. 7I-79.

I8. Gunnar Mickwitz, Die Kartellfunktionen der Zünfte und ibre Bedeutung bei der Entstehung des Zunftwesens. Eine Studie in spätantiker und mittelalterlicher Wirtschaftsgeschichte (Helsinki, 1936), pp. 24-25, 32-35, 42-43, 58-6I.

19. Simona Cerutti, "Du corps au métier: la corporation des tailleurs à Turin entre le XVIIe et le XVIIIe siècle”, Annales ESC, 43 (1988), pp. 323-352, and idem, La ville et les métiers. Naissance d'un langage corporatif: Turin, XVIIe-XVIIIe siècles (Paris, I990). 
the prohibition that barred master silk weavers throughout Italy from selling their manufactures directly, blocking the rise of a group of industrial entrepreneurs in this branch, with sweeping consequences.

\section{FLANDERS AND BRABANT: POWERFUL CRAFT GUILDS}

The county of Flanders resembled northern Italy in the central and late Middle Ages in that it was highly urbanized and had several major textile centres, and that urban corporatism arose relatively early, but the two differed in one fundamental respect: in Flemish cities and towns master artisans producing for export markets collectively controlled their guilds, and the more affluent members of the craft guilds were important in local politics. The "powerful craft guilds" in Flanders were thus entirely different from the guilds in northern Italy. This had various socio-economic implications as well. We will start by considering the political constellation.

The last quarter of the thirteenth century was a period of socio-economic as well as political transition in many Flemish, north-west-French, and German cities and towns, as is clear from the frequent and violent revolts, in which master artisans were increasingly in the vanguard. Some movements involving textile workers arose primarily from social causes, but in other cases the demands made of the municipal authorities had political implications: a fairer justice system, more responsible fiscal policy, and, last but not least, participation in the city council. The fact that various groups with divergent and even conflicting interests were vying for political power from around I 300 onward was decisive in the emancipation struggle of the Flemish master artisans. Local and supralocal levels became inextricably linked with one another in the process.

The rivalry between the king of France and the count of Flanders sowed dissent among the Flemish aristocracy and the urban elite alike; many members of the Bruges "patricians" sided with the king. These Leliaerds or Lilies opposed the commons, a heterogeneous coalition comprising rich burghers deprived of a place in urban government and the mass of master artisans, who were known as Klawwaards or Claws. ${ }^{20}$ Although in 1302 the French noblemen suffered a crushing defeat in the

20. David Nicholas, Medieval Flanders (London [etc.], I992), pp. I86-208 (with references to the literature); Marc Boone, "Une société urbanisée sous tension: le comté de Flandre vers I 302", in R.C. van Caenegem (ed.), 1302: Le désastre de Courtrai. Mythe et réalité de la bataille des Éperons d'Or (Antwerp, 2002), pp. 65-66, and idem, "Armes, coursses, assemblées et commocions. Les gens de métiers et l'usage de la violence dans la société urbaine flamande à la fin du Moyen Age", Revue du Nord, 87 (2005), pp. 9-10, I4-15; Thomas A. Boogaart II, An Ethnography of Late Medieval Bruges: Evolution of the Corporate Milieu, I280-I349 (Lewiston, ME, 2004), pp. $25 \mathrm{I}-255$; Jan Dumolyn and Jelle Haemers, "Patterns of Urban Rebellion in Medieval Flanders", Journal of Medieval History, 3 I (2005), pp. 369-393, esp. $372-378$. 
famous Battle of the Golden Spurs at Courtrai, the master artisans were unable to cash in immediately on the victory in which they had played an important part because of the complex power struggle within the cities and towns.

Ultimately, however, the craft guilds managed to shift the balance of power in their favour through these changing coalitions: from the $1360 \mathrm{~s}$ onward, the deacons of the craft guilds, including those of the wool weavers in Bruges, Ghent, and Ypres, acquired a say in local politics, as they did in several small towns as well. Their actual participation derived from the remuneration that these members of corporative organizations started receiving for holding political office, which relieved them of the impossible dilemma between being politically active and having no income or being economically active and leaving politics. In practice, the power rested with a corporative elite: affluent masters who were elected as deacons in most craft guilds and served on the city council. ${ }^{21}$ Unlike in northern Italy, however, representatives of corporative organizations in late medieval Flanders were in any case master artisans, both in the sectors serving the local market and in the export-oriented trades.

What were the socio-economic consequences of this power constellation, especially with respect to the development of the Flemish textile trades? During the period of political emancipation for the craft guilds, changes occurred in trade and industry that basically benefited the direct producers. Because both the costs of selling export goods and the risks associated with transport declined during the fourteenth century, master artisans manufacturing luxury cloths became far less dependent on merchants and financiers and were thus in a far better position to launch entrepreneurial initiatives. ${ }^{22}$ They were able to benefit from the new conditions, however, thanks to a combination of three factors, which were the outcome of the changed political balance of power.

Firstly, precisely because corporative organizations had a say in local politics, merchants in the Flemish cities and towns were unable to control

21. Willem Pieter Blockmans, De volksvertegenwoordiging in Vlaanderen in de overgang van Middeleewwen naar Nieuwe Tijden, I384-1 506 (Brussels, I978), pp. 72-8 I; Nicholas, Medieval Flanders, pp. 242-246; Marc Boone, "Les métiers dans les villes flamandes au bas Moyen Âge (XIVe-XVIe siècles): Images normatives, réalités socio-politiques et économiques”, in Pascale Lambrechts and Jean-Pierre Sosson (eds), Les métiers au Moyen Âge. Aspects économiques et sociaux. Actes du Colloque international de Louvain-la-Neuve, 7-9 octobre 1993 (Louvain-laNeuve, I994), pp. 6-I 2, and idem, "Städtische Selbstverwaltungsorgane vom I4. bis I6. Jahrhundert. Verfassungsnorm und Verwaltungswirklichkeit im Spätmittelalterlichen flämischen Raum am Beispiel Gent”, in Wilfried Ehbrecht (ed.), Verwaltung und Politik in Städten Mitteleuropas (Cologne [etc.], 1994), pp. 26, 45-46; Peter Stabel, De kleine stad in Vlaanderen. Bevolkingsdynamiek en economische functies van de kleine en secundaire stedelijke centra in het Gentse kwartier (I4de-I6de eeww) (Brussels, 1995), pp. I44-I46, 203-204, 222-226.

22. Holbach, Frühformen, pp. 223 and 233. 
craft guilds from within, which basically barred them from membership, unless they agreed to comply with all corporative regulations, including serving a term of apprenticeship. Secondly, these corporative organizations could not prohibit master artisans from selling their own manufactures. And, thirdly, they were not in a position either to prevent master artisans from resorting to subcontracting. The charters of the weavers' guilds and other guild-based occupational groups - did in fact tacitly overlook subcontracting.

In his in-depth study, the late Jos Vermaut revealed that this flexible system was widespread in the Bruges cloth industry in the fourteenth and fifteenth centuries. He identified four producer groups with very unequal socio-economic positions: first, a small number of affluent drapers who purchased their wool from merchants, owned their own workshops, and acted as principal contractors; second, "humble" drapers, who obtained their wool from their more affluent colleagues but processed their raw materials at their own expense; third, conventers, i.e. master weavers who owned production equipment but were sub-contractors working at piecework rates for affluent drapers who supplied the wool on credit; and, fourth, proletarianized masters who performed wage labour at workshops owned by others. Since drapers were prohibited from having over four looms in their workshops, no large industrial establishments emerged in Bruges. Despite the small size of the individual workshops, however, corporative restrictions on the number of looms per workshop were easy to circumvent by using conventers. Accordingly, by the end of the fifteenth century, the wool weavers' guild in Bruges consisted primarily of conventers, who worked for a small group of capitalist drapers. ${ }^{23}$

In the duchy of Brabant the political emancipation of the craft guilds occurred somewhat later than it did in the county of Flanders, because Brabant's cities and towns were less economically significant, because fewer master artisans manufactured cloth there, and, last but not least, because fewer opportunities were available to form coalitions with powerful groups within and outside the cities and towns. Only in the late fourteenth and early fifteenth centuries did corporative organizations acquire a say in urban politics. In Louvain, Brussels, and 's-Hertogenbosch, three of the four "capitals" of the duchy, and in many other centres as well, they were henceforth able to participate in the local council directly or indirectly. In Antwerp, the fourth capital, they were unable to negotiate a representative at the magistrate level, but they tipped the scales on the councils that decided about public finance and economic affairs concerning

23. Jos Vermaut, "De textielnijverheid in Brugge en op het platteland in westelijk Vlaanderen voor I 800 . Konjunktuurverloop, organisatie en sociale verhoudingen" (Ph.D., University of Ghent, 1974), pp. 480-489. 
the city as a whole, leaving the ruling elite with no choice but to accommodate them. ${ }^{24}$

During the early modern period, the importance of the craft guilds in the capitals extended considerably beyond the local context, as they effectively decided whether a request from the ruler for a new aide (which generally meant new or higher taxes) in the states of Brabant would be approved: unanimous approval was required, and the yea or nay of the Third Estate depended on what the guilds had decided in the capitals. ${ }^{25}$ Since they commanded the vote in the second most densely populated and most affluent province in the Habsburg Netherlands, the craft guilds in the Brabant capitals influenced "national" politics until the end of the ancien régime. In the cities and towns of the other provinces that formed the Habsburg - first the Spanish and later the Austrian - Netherlands between I482 and I795, craft guilds were less economically influential than their Flemish counterparts and had less clout than their Brabant counterparts in economic affairs and politics alike. Still, their significance is not to be underestimated: as in the other provinces mentioned, merchants were not allowed to join guilds responsible for manufacturing goods. On the other hand, master artisans were entitled to sell their own manufactures directly and to use subcontracting. ${ }^{26}$

Considering these circumstances, the ongoing special consideration for the craft guilds on the part of the central government is understandable. On the one hand, these organizations met with suspicion. Following the conquest of Tournai in I $52 \mathrm{I}$, and the annexation of Utrecht in I528, Emperor Charles V immediately revoked the political rights of the local craft

24. Carlos Wyffels, De oorsprong der ambachten in Vlaanderen en Brabant (Brussels, I95 I); Raymond Van Uytven, "Vorst, adel en steden: een driehoeksverhouding in Brabant van de twaalfde tot de zestiende eeuw", Bijdragen tot de Geschiedenis, 59 (1976), pp. 93-1 22, and idem, "Stadsgeschiedenis in het Noorden en het Zuiden", in H.P.H. Jansen and R.C. van Caenegem (eds), Algemene Geschiedenis der Nederlanden, II: Middeleewwen (Haarlem, I982), pp. 210-213; Marc Jacobs, "De ambachten in Brabant en Mechelen (I2de eeuw-1795)", in Raymond Van Uytven et al. (eds), De gewestelijke en lokale overbeidsinstellingen in Brabant en Mechelen tot 1795 (Brussels, 2000), pp. 558-624.

25. For additional details, see Karin Van Honacker, Lokaal verzet en oproer in de I 7 de en I8de eeuw. Collectieve acties tegen het centraal gezag in Brussel, Antwerpen en Lewven (Kortrijk [etc.], I994), pp. 90-95, I 37-I42, I62-164, and the literature cited there.

26. See inter alia J.-B. Goetstouwers, Les métiers de Namur sous l'Ancien Régime. Contribution à l'histoire sociale (Louvain [etc.], I908); G. Wymans, "Origine et croissance des connétablies de métiers à Mons (XIIIe-XVe siècle)", Archives et Bibliothèques de Belgique, 36 (1965), pp. I 5-34; Jean-Jacques Heirwegh, "Corporations, économie urbaine et gouvernement dans les Pays-Bas autrichiens, I738-1784" (Ph.D., Brussels, ULB, I98I), as well as idem, "Artisanat et industrie à Mons au XVIIIe siècle", in Recueil d'études d'histoire hainuyère offertes à Maurice A. Arnould, I (Mons, I983), pp. 291-317; Philippe Guignet, Le pouvoir dans la ville an XVIIIe siècle. Pratiques politiques, notabilité et éthique sociale de part et d'autre de la frontière franco-belge (Paris, 1990), pp. 61-72, 290-3 I 4; Jean-Marie Cauchies, "Règlements de métiers et rapports de pouvoirs en Hainaut à la fin du Moyen Age”, in Lambrechts and Sosson, Les métiers, pp. 35-54. 
guilds. And after the uprising in I 539 he prohibited the master artisans of Ghent from electing their own deacons; henceforth the corporations were run by "superiors", who had to be members of the urban elite and were not allowed to engage in an occupation. ${ }^{27}$ Until the 1780 s, however, no efforts were made in the southern Netherlands to curtail urban corporatism as such. The craft guilds were too powerful in too many cities and towns and, moreover, had solid constitutional foundations in some provinces. Emperor Joseph II did not seek to abolish them but aimed merely to impose official control.

On the other hand, it became clear after is85 that wholesale trade could no longer act as the main driver of urban economies. The central government therefore tended to arbitrate in disputes between (urban) industry and commerce in favour of the producers - even when said producers were master artisans. The guild-based organization of many export trades therefore certainly did not prevent industrial interests from prevailing over the logic of commercial capital. After the Treaty of Aixla-Chapelle ( 1748 ) this was particularly important, as the government of the Austrian Netherlands was finally in a position to enforce a true customs policy. The incentives and protective measures introduced at that point greatly contributed to the success of various urban export trades. ${ }^{28}$

The remarkable resilience of the urban export trades in the southern Netherlands, especially in Flanders and Brabant between the thirteenth century and the end of the ancien régime, was attributable to several factors, of course, but urban corporatism was an integral part of this success story. The four or five consecutive cycles of product innovation and product differentiation were "supported" not by merchant entrepreneurs but by affluent master artisans operating as industrial capitalists. ${ }^{29}$ The introduction of new manufactures was greatly encouraged because these master artisans achieved economies of scale thanks to the combination of subcontracting and commercial activities, and because they often wielded administrative control within their guild, giving them substantial influence in decisions that were binding on all members. ${ }^{3 \circ}$ Because wealthy producers (rather than

27. Johan Dambruyne, Corporatieve middengroepen. Aspiraties, relaties en transformaties in de I6de-eeuwse Gentse ambachtswereld (Ghent, 2002), pp. 34-38, 294-295.

28. Catharina Lis and Hugo Soly, "Export Industries, Craft Guilds and Capitalist Trajectories, I 3 th to I 8th Centuries", in Maarten Prak et al. (eds), Craft Guilds in the Early Modern Low Countries: Work, Power and Representation (Aldershot, 2006), pp. I 26-I 27 (with references to the literature).

29. See Herman van der Wee, "Industrial Dynamics and the Process of Urbanization and DeUrbanization in the Low Countries from the Late Middle Ages to the Eighteenth Century: A Synthesis", in idem (ed.), The Rise and Decline of Urban Industries in Italy and the Low Countries (Late Middle Ages-Early Modern Times) (Louvain, I988), pp. 307-38 I.

30. For additional details, see Lis and Soly, "Export Industries", pp. I28-130, and idem, "Subcontracting". 
merchants) controlled the guilds and, moreover, had a say in politics, nearly always locally and sometimes supralocally as well, the resulting dynamics of the urban textile trades in Flanders and Brabant were not dictated entirely by the logic of circulating capital. The foundations of this political economy were established during the late Middle Ages, when the constellation of power enabled producers not only to establish formal guilds recognized by the public authorities but also to formulate the rules and regulations in export trades so as to exclude merchants while at the same time leaving institutional gaps that made certain entrepreneurial initiatives possible.

\section{GERMAN GUILDS AND THE “REHABILITATION THESIS"}

Corporatism in late medieval Germany was a far more complex system than in northern Italy or Flanders. Like their counterparts in the latter two regions, many German cities obtained considerable political autonomy, and the Reichsstädte, imperial cities, became so powerful that they managed to discard all extraneous lordship and to have their own representatives at the Reichstage (imperial diets). In some cases the struggle to become politically autonomous and subsequently participate in the local council exclusively or primarily benefited the merchants, while in other cases the master artisans obtained power or at least political input. Understandably, the nature of the urban economy largely determined which groups carried the most weight.

In the north German seaports, such as Lübeck (one of the leading cities in the Hanseatic League from the second half of the thirteenth century), Hamburg, and Wismar, where export industries were of only secondary importance, and the overwhelming majority of the craftsmen therefore worked for the local market, the merchants gained the upper hand. ${ }^{3 \mathrm{I}}$ After the uprising in $\mathrm{I} 384$, the craft guilds in Lübeck lost even their - very limited - judicial powers and became institutions serving the municipal authorities. Protests from manual workers demanding constitutional amendments resulted in Verhansung in Braunschweig ( 1375 ), Stettin (I420), and Bremen (I426), i.e. the exclusion of these cities from the Hanseatic League.

In the Rhineland and in southern Germany, where a great many exportoriented textile trades were coming into being, the situation was more complicated. After the emerging urban communes sought political emancipation from their feudal overlords in the second half of the eleventh and the twelfth centuries, guilds in several cities and towns struggled during the thirteenth, and especially the fourteenth, centuries to participate in local councils, which nearly everywhere were controlled by a few "patrician" families. As in Flanders, many master artisans working in the rapidly expanding export trades took the lead and teamed up with other groups, including coalitions with the established elite, as well as with merchants 
and other members of the nouveaux riches. In several imperial cities these Bürgerkämpfe or civic struggles, as most historians now describe the conflicts within cities, became closely linked during the first half of the fourteenth century with the struggle for the royal and imperial crown, which erupted in I 3 I 4 and greatly deepened local polarization.

The sovereigns intervened in conflicts within cities on pragmatic grounds, which meant that they supported the local coalitions that benefited them the most. In some cities they introduced a Zunftverfassung (guild-based constitution) or upheld it, while in others they did the opposite, terminating the participation of the guilds or strengthening the "patriciate". ${ }^{32}$ In Nuremberg (I 349), a top metal-processing centre, and in Frankfurt-am-Main (I 366), a commercial centre, Emperor Charles IV stripped the guilds entirely of their say in politics and transferred all control over them to the municipal authorities, which henceforth consisted of powerful international dealers and merchant entrepreneurs. Nuremberg remained a "city without guilds" until well into the nineteenth century: master artisans were not even allowed to form confraternities; the city council organized the different occupations,

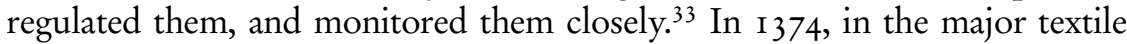
centre of Augsburg, on the other hand, the emperor upheld the political participation that the craft guilds had obtained following a non-violent coup six years earlier, because the new city council gave him financial support. Note, however, that the weavers' guild there had included merchant entrepreneurs among its members from the outset and still did in the late fifteenth and early sixteenth centuries, as several members of the Fugger family belonged to this guild. ${ }^{34}$

32. Eberhard Isenmann, Die deutsche Stadt im Spätmittelalter, I250-I500. Stadtgestalt, Recht, Stadtregiment, Kirche, Gesellschaft, Wirtschaft (Stuttgart, 1988), pp. 190-198, and the literature cited on pp. 207-209. See also Peter Johanek, "Bürgerkämpfe und Verfassung in den mittelalterlichen deutschen Städten", in Hans Eugen Specker (ed.), Einwohner und Bürger auf dem Weg zur Demokratie. Von den antiken Stadtrepubliken zur modernen Kommunalverfassung (Ulm, 1997), pp. $45-73$.

33. Hans Lentze, "Nürnbergs Gewerbeverfassung im Mittelalter", Jabrbuch für fränkische Landesforschung, 24 (1964), pp. 207-281, and idem, "Nürnbergs Gewerbeverfassung des Spätmittelalters im Rahmen der deutschen Entwicklung”, in Beiträge zur Wirtschaftsgeschichte Nürnbergs, II (Nuremberg, 1967), pp. 593-619; Rudolf Endres, "Zur Lage der Nürnberger Handwerkerschaft zur Zeit von Hans Sachs", Jabrbuch für fränkische Landesforschung, 37 (1977), pp. I07-I23; W. Lehnert, "Nürnberg: Stadt ohne Zünfte. Die Aufgaben des reichsstädtischen Rugamts", in Rainer S. Elkar (ed.), Deutsches Handwerk im Spätmittelalter und früber Neuzeit (Göttingen, I983), pp. 7I-8I.

34. Friedrich Blendinger, "Die Zunfterhebung von I 368 in der Reichsstadt Augsburg. Ihre Voraussetzungen, Durchführung und Auswirkung”, in Franz Quarthal and Wilfried Setzler (eds), Stadtverfassung, Verfassungsstaat, Pressepolitik. Festschrift für Eberhard Naujoks zum 65. Geburtstag (Sigmaringen, 1980), pp. 71-90; Jörg Rogge, Für den Gemeinen Nützen. Politisches Handeln und Politikverständnis von Rat und Bürgerschaft in Augsburg im Spätmittelalter (Tübingen, I996), pp. 107-I I8. 
In most cities with very advanced textile industries, guild-based organizations obtained a say in politics at some point, both in the Rhineland and southern Germany and in the area that is now Switzerland. Such power existed in various manifestations, however, and determined the economic leverage available to the master artisans. The adoption of a guild constitution was not necessarily a sign that the producers of export goods were powerful, as the examples of Strasbourg and Ulm demonstrate. In Strasbourg the ones to benefit from the power struggle during the late Middle Ages were not the wool weavers but the Tucher, the cloth merchants organized in a guild. The support these Tucher received from the political elite basically prevented the textile producers from gaining access to the market. ${ }^{35}$ In Ulm, where the balances of power shifted constantly during the late Middle Ages, the Council - on which the merchants' and mercers' guilds were well represented - never granted the urban fustian weavers a production monopoly and always allowed their rural competitors, who manufactured larger quantities at lower prices, to sell their textile goods on the town market; in I 575 the master weavers were in fact prohibited from subcontracting to colleagues or purchasing the textiles they produced. ${ }^{36}$

In Cologne, the largest and most powerful city of the Rhineland and the most economically dynamic city in medieval Germany, on the other hand, the political constellation was closely linked to the rise of a corporatism giving master artisans economic leeway and enabling them to organize production. From the thirteenth century onward, craft guilds struggled against the ruling elite there (with the role of the archbishop alternating between that of an ally and an adversary), used the rivalry between patrician families to their advantage, and formed coalitions with merchants lacking political power. In I 396 an extended series of conflicts culminated in a new constitution establishing a guilds' council: the members of the new council were henceforth elected. The craft guilds held the majority of the seats, with the Wollenamt, the wool weavers' guild, emerging as the strongest group. A limited number of corporative organizations (known as "political guilds") dominated the council, and their representatives

35. Martin Alioth, Gruppen an der Macht: Zünfte und Patriziat in Strassburg im I4. und Is. Jabrhundert. Untersuchungen zu Verfassung, Wirtschaftsgefüge und Sozialstruktur (Basle [etc.], 1988).

36. Eugen Nübling, Ulms Baumwollweberei im Mittelalter. Urkunden und Darstellung (Leipzig, I890); Rolf Kiessling, Die Stadt und ihr Land. Umlandpolitik, Bürgerbesitz und Wirtschaftsgefüge in Ostschwaben vom I4. bis ins I6. Jahrbundert (Cologne [etc.], 1989), pp. 479-48 I, 49I, 752-760; Anke Sczesny, "Stadt, Markt und Land im Textilrevier Ostschwabens im 17. und 18. Jahrhundert", in Mark Häberlein and Christof Jeggle (eds), Vorindustrielles Gewerbe. Handwerkliche Produktion und Arbeitsbeziebungen in Mittelalter und früher Neuzeit [IRSEER Schriften: Studien zur schwäbischen Kulturgeschichte, new series, II] (Constance, 2004), pp. 67, $75-76$. 
were all affluent producers. The consequences quickly materialized: in I 400 the public authorities stipulated that only members of the Wollenamt were entitled to use subcontracting in the wool industry. And they did in fact apply the system extensively: throughout the fifteenth century the overwhelming majority of the master wool weavers worked directly or indirectly for affluent colleagues who supplied the wool - either by purchasing it or by raising sheep - and sold the textiles, both at the fairs of Frankfurt and Brabant and throughout southern Germany, Austria, and south-east Europe. ${ }^{37}$ At other major textile centres, including those in Dortmund, the political emancipation of the guilds also enabled affluent master artisans in the late Middle Ages to confront the merchants as autonomous entrepreneurs: they supervised the guilds and were allowed to trade and to use subcontracting, enabling them to organize production themselves. ${ }^{38}$

In the early sixteenth century, especially in the period I5II-I530, Germany experienced numerous and often violent Bürgerkämpfe that arose from complex causes. ${ }^{39}$ Their prevalence in cities and towns with highly advanced textile industries and the long lists of grievances about mismanagement and wrongdoings submitted to the city councils suggest, ${ }^{4}$ however, that craft guild representatives had mainly looked out for their own interests during the previous decades. At any rate, between I 548 and I555 Emperor Charles $\mathrm{V}$ abolished the political input of the corporative organizations in Augsburg, Memmingen, and twenty-five other Reichsstädte; he transferred control to an oligarchy of merchants and members of patrician families, who continued to run the cities until well into the nineteenth century. ${ }^{4 \mathrm{I}}$

Still, merchant capital never gained complete supremacy in the export trades in these cities. Even though the craft guilds no longer participated in the Council, the local elites were not automatically able to turn back the clock, as far as the organization of industrial production was concerned. The Augsburg weavers, for example, continued to defend their

37. Franz Irsigler, Die wirtschaftliche Stellung der Stadt Köln im I4. und I5. Jabrbundert. Strukturalyse einer spätmittelalterlichen Exportgewerbe- und Fernhandelsstadt [Vierteljahrschrift für Sozial- und Wirtschaftsgeschichte, Beiheft no. 65] (Wiesbaden, 1979), pp. 37-6I. The same author demonstrates that some master armourers in Cologne formed vast subcontracting networks as well (pp. 208-215).

38. Holbach, Frühformen, pp. 102 and ros.

39. Erich Maschke, "Deutsche Städte am Ausgang des Mittelalters", in Wilhelm Rausch (ed.),

Die Stadt am Ausgang des Mittelalters [Beiträge zur Geschichte der Städte Mitteleuropas, III] (Linz, 1974), p. 40.

40. Peter Blickle, Unruben in der ständischen Gesellschaft, I300-I800 (Munich, I988), pp. $25-28$, and the literature cited there.

4I. Eberhard Naujoks, Kaiser Karl V. und die Zunftverfassung. Ausgewählte Aktenstücke zu den Verfassungsänderungen in den oberdeutschen Reichsstädten, I547-I556 (Stuttgart, 1985 ). 
interests through their former organization, known from that point on as a "craft", while data from I610 indicate that a tiny minority of the 2, 100 guild members were very affluent, justifying the hypothesis that they made extensive use of subcontracting and sold their products as well. ${ }^{42}$ The master artisans of Ghent also seem to have been able to continue using subcontracting and to engage in trade after the institutional reorganization of I $540{ }^{43}$ In textile centres where the guilds retained their say in politics, no major changes occurred. In I6I6 the city council of Cologne reaffirmed the principle that only members of the Wollenamt were entitled to act as contractors. As a consequence, merchant capital did not control the urban textile trade there in the seventeenth and eighteenth centuries. ${ }^{44}$

The research available at this time does not enable us to shed light on all institutional variations in the organization of the urban textile trades or to evaluate their economic consequences in medieval and early modern Germany. Undoubtedly, however, the power constellation favoured direct producers in several cities and towns during the thirteenth and fourteenth centuries. They were able to organize, and they obtained a say in politics as well; in several cities they even negotiated a Zunftverfassung. As in Flanders, the presence of powerful craft guilds in German cities meant that the more substantial master artisans involved in textile manufacturing had considerable economic leverage: they were in a position to launch entrepreneurial initiatives. This gave rise to social polarization within the weavers' guilds. The dominance of a small group of masters facilitated adaptations to changes, especially the introduction of new textile goods. In such cases the logic of merchant capital did not prevail, and a specific industrial dynamics evolved.

This aspect merits mention because Sheilagh Ogilvie, in a recent welldocumented article, has used the example of German proto-industry to argue that the protagonists of the "rehabilitation thesis" are mistaken. She argues that the empirical data on the guild-based worsted industry in the Black Forest region of Württemberg during the early modern period demonstrate that "powerful guilds" were unable to respond efficiently to economic changes. This conclusion is particularly significant, because, according to the author, "Württemberg with its active guilds and stagnant

42. Claus-Peter Clasen, Die Augsburger Weber. Leistungen und Krisen des Textilgewerbes um I600 (Augsburg, I98 I), pp. 3 I-33, 82-85, 237-260, 286-289, 330-332. While the extent to which merchants used the Verlagssystem in sixteenth-century Augsburg is a subject of debate, the master weavers there are known to have used subcontractors. See Mark Häberlein, "Weber und Kaufleute im I6. Jahrhundert: Zur Problematik des Verlagswesens in der Reichsstadt Augsburg", Zeitschrift des Historischen Vereins für Schwaben, 9I (1998), pp. 43-56.

43. Dambruyne, Corporatieve middengroepen, pp. 59-72.

44. Dietrich Ebeling, Bürgertum und Pöbel. Wirtschaft und Gesellschaft Kölns im I8. Jabrhundert (Cologne [etc.], I987), pp. 36-4I. 
economy was closer to the norm than more dynamic preindustrial European economies such as the Low Countries or England".45

Although the area examined is incorrectly described as typical of many European proto-industrial regions,${ }^{46}$ the conclusion is probably accurate, albeit for reasons other than the ones provided by the author. The institutional structure of Württemberg's serge industry consisted on the one hand of the rural weavers, who became incorporated and obtained state charters between I 589 and I6II, and on the other hand of the merchant dyers in the small town of Calw, who formed a guild-like association and obtained a state charter as well. Significantly, the members of the Calwer Zeughandlungskompagnie, as the association was known, acquired the monopoly on dyeing and exporting the serges and fustians, and all weavers were required to sell their textile goods exclusively to them. Prices and quotas were set collectively through periodic negotiations between the two groups, supervised by the state. It is easy to guess which party consistently benefited most from this arrangement. In 1680 and I740 the weavers campaigned for more favourable legislation against the Calwer Zeughandlungskompagnie, but the merchant dyers easily prevailed, thanks to their family connections with local officials, their frequent bribes, and their massive state loans.

Because of the preponderance of commercial capital, much-needed product innovation was not forthcoming or was greatly delayed during the eighteenth century: merchant dyers were willing to introduce new types of serge only if these were included in their purchase privileges, which required extensive lobbying and thus became very time-consuming and costly. ${ }^{47}$ In the linen industry the situation was no different: from the mid-seventeenth century both the urban and the rural weavers in Württemberg were required to sell their finished products to the Uracher Leinwandhandlungskompagnie. Although the merchants never gained total control of the production line, their legal monopoly made it exceedingly difficult for the weavers to launch true entrepreneurial initiatives. In the mid-eighteenth century the latter unsuccessfully petitioned the duke on various occasions for "freedom to trade and make a

45. Ogilvie, “Guilds”, p. 33 I.

46. Quantification is impossible at this time, but the available data suggest that in most protoindustrial regions rural weavers were not organized in guilds. The spread of rural guilds was a specific characteristic of central European regions in the early modern period, as Josef Ehmer rightly observes in "Rural Guilds and Urban-Rural Guild Relations in Early Modern Central Europe" in this volume.

47. Ogilvie, "Guilds", pp. 289-290, 298, 321, 327-328. The title of the path-breaking study by Walter Troeltsch, Die Calwer Zeughandlungskompagnie und ibre Arbeiter (Jena, I897), accurately reflects the relationship between the merchant dyers and the rural weavers: the latter "worked" for the former. 
fair profit", and their subsequent boycott of the supply led to the imprisonment of the leading "insurgents". ${ }^{8}$

The Württemberg proto-industry was therefore controlled not by powerful craft guilds but by guild-like associations of merchant entrepreneurs, who left the weavers no opportunity to launch their own initiatives; the only choice available to the weavers was to accept or reject the proposals from the merchant entrepreneurs. Accordingly, the example from the Black Forest region does not automatically answer the question as to whether craft guilds were efficient institutional arrangements that benefited the local or regional economy. Only highly autonomous craft guilds could do so, which meant in economic terms that master artisans producing export goods were not entirely at the whim of merchants. The shortcomings of the "rehabilitation thesis" are that in late medieval and early modern Europe the regions where guild-based textile trades were ruled by the logic of merchant capital are likely to have outnumbered the ones where they were able to develop their own dynamics.

\section{THE DUTCH REPUBLIC AND THE LOGIC OF MERCHANT CAPITAL}

The northern Netherlands, where craft guilds started to proliferate only in the fifteenth century because of the relatively late urbanization and industrial development in this area, illustrates the institutional lack of power among most producers. In very few cities, craft guilds became true forces in local politics for brief or extended periods; their success was usually attributable to the impasse between various power groups, enabling them to form coalitions. This was the case in Dordrecht (the oldest city in the county of Holland), in Middelburg and Zierikzee (in the county of Zeeland), in Utrecht (in the homonymous bishopric), as well as in Arnhem, Zutphen, and a few other towns in the duchy of Gelderland in the east. ${ }^{49}$ During the first

48. Hans Medick, "Freihandel für die Zunft. Ein Kapitel aus der Geschichte der Preiskämpfe im württembergischen Leinengewerbe des I8. Jahrhunderts", in Mentalitäten und Lebensverbältnisse. Beispiele aus der Sozialgeschichte der Neuzeit. Rudolf Vierhaus zum 60. Geburtstag (Göttingen, I982), pp. 277-294. In Lower Silesia the course of events was similar: from the midseventeenth century only members of the merchants' guilds were entitled to purchase and export linens; these commercial organizations blocked both product and process innovation to protect their interests. See Marcel Boldorf, "Entwicklung und institutionelle Rahmenbedingungen: Die Beispiele Niederschlesien und Nordirland (1750-1850)", Vierteljabrschrift für Sozial- und Wirtschaftsgeschichte, 90 (2003), pp. 399-4I 5.

49. On Dordrecht: Peter Schotel, "Strijd om de macht", in Willem Frijhoff, Henk Nusteling, and Marijke Spies (eds), Geschiedenis van Dordrecht van 1572 tot ${ }_{1813}$ (Hilversum, 1998), pp. I 5-37. On Middelburg: W.S. Unger, Bronnen tot de geschiedenis van Middelburg in den landsheerlijken tijd, I (The Hague, I923). For Utrecht: Maarten Prak, "Politik, Kultur und politische Kultur: die Zünfte in den Nördlichen Niederlanden”, in Wilfried Reininghaus (ed.), Zunftlandschaften in Deutschland und den Niederlanden im Vergleich (Münster, 2000), 
half of the sixteenth century, Emperor Charles V excluded the craft guilds in Zeeland and Utrecht from formal political participation.

The emergence of the Republic of the Seven United Provinces, known as the Dutch Republic for short, did not increase the political leverage of corporative organizations. On the contrary, the spectacular urban growth coincided with an equally impressive rise in the number of corporative organizations, ${ }^{50}$ but primarily outside the export trades, and, except for towns in the eastern provinces, master artisans did not have direct political input anywhere. Not only was the urban elite - which in the seventeenth century consisted largely of merchants, and in the eighteenth century included increasing numbers of rentiers - in control at all local and supralocal political institutions, the city councils closely supervised the guild officials as well. In Amsterdam, where the deacons were appointed annually by the burgomasters, the one assigned a seat on the city council in the very exceptional year of 1747 happened to be an extremely wealthy wine merchant. ${ }^{5 \mathrm{I}}$ Amsterdam was a "merchants' city" indeed, as contemporaries observed. The organization of the export trades reveals the extent to which the interests of this global depot and of the wholesalers tended to prevail.

The overwhelming majority of the textile producers in the United Provinces, employers and employees alike, operated outside the corporative context. Only a tiny minority of the thousands of manual artisans working for the new drapery in Leiden (the most important textile centre) belonged to a craft guild. Nor were the wool weavers and silk weavers in Amsterdam, the linen bleachers in Haarlem, the cloth weavers in Delft, or the producers of serges and fustians in Gouda organized in guilds. This did not mean, however, that no regulations or control mechanisms existed in these cities. Nearly the entire textile industry in Leiden was organized in neringen (trades). All persons involved in manufacturing a certain product automatically belonged to these neringen: there was no formal membership

pp. 76-80. On Arnhem: C.L. Verkerk, Coulissen van de macht. Een sociaal-institutionele studie betreffende de samenstelling van het bestuur van Arnhem in de Middeleeuwen en een bijdrage tot de studie van stedelijke elitevorming [Amsterdamse Historisch Reeks, Grote Serie I4] (Hilversum, 1992). See also the survey by Maarten Prak, "Corporate Politics in the Low Countries: Guilds as Institutions, I4th to I8th Centuries", in Prak, Craft Guilds in the Early Modern Low Countries, pp. 88-92.

50. Piet Lourens and Jan Lucassen, "De oprichting en ontwikkeling van ambachtsgilden in Nederland (I3de-Igde eeuw)", in Catharina Lis and Hugo Soly (eds), Werelden van verschil. Ambachtsgilden in de Lage Landen (Brussels, 1997), pp. 43-78, and Piet Lourens and Jan Lucassen, Inwoneraantallen in Nederlandse steden, ca. I300-ca. I 800 (Amsterdam, I997). See too Bert De Munck, Piet Lourens, and Jan Lucassen, "The Establishment and Distribution of Craft Guilds in the Low Countries I000-I 800", in Prak, Craft Guilds in the Early Modern Low Countries, pp. $37-40$.

5. Prak, "Corporate Politics", pp. го0-103, I05. 
procedure, with conditions for joining and the right to withdraw. The same or similar institutions existed in Amsterdam, Haarlem, Delft, and Gouda and were supervised by the municipal authorities there as well.

Wherever branches of the textile industry were guild-based, the master artisans had no real decision-making authority. They would be consulted, and in most cases their recommendations would be adopted (especially concerning technical matters), but the local authorities were in full control. The authorities used the corporative organizations, where they appointed those in charge, as instruments for protecting economic and/or fiscal interests that did not necessarily top the agendas of the master artisans. This was all the more true, because the city councils ensured that the merchants were represented on the bodies supervising export-oriented craft guilds or neringen. In some branches of the textile industry the direct producers were prohibited from trading and they lost out in all conflicts between commercial and industrial interests. The Amsterdam wholesalers were so dominant, both in the capital and in other export centres, that the States of Holland and the States General nearly always refused to take protectionist measures favouring the manufacturers. Even when the labour-intensive textile trades could no longer compete with the competition from abroad in the eighteenth century, the logic of merchant capital continued to prevail, leading ultimately to de-industrialization. ${ }^{52}$

\section{CRAFT GUILDS IN STRONG MONARCHIES}

In centralized states, craft guilds evolved in entirely different ways, and their impact on the urban textile trades varied accordingly. ${ }^{53}$ The decisive factors were whether and to what extent rulers needed the support of the cities, and whether they needed to consider competing lobby groups within the cities. In some countries urban producers of export goods, whether or not they were guild-based, were at a serious disadvantage for political and socio-economic reasons. In late medieval and early modern Castile, for example, they generally had little political influence, because very few important industrial centres existed there, and because in nearly all cases they faced an alliance of merchants and noblemen whose material interests conflicted with those of the textile manufacturers. Moreover, following the defeat of the comuneros in I 52 I the monarchy nearly always sided with the pressure groups that benefited from the export of raw materials (especially wool) and from the import of finished goods; rulers might also refuse to take effective protectionist measures because of tax

52. For more detail, see Lis and Soly, "Export Industries", pp. I I 5-I I6, I 22-I 23, I 27-I 28, I 3 I, and the literature cited there.

53. In England and France production of textile goods shifted progressively to the countryside during the early modern period, but few of these protoindustrial regions were guild-based. 
revenues. ${ }^{54}$ The complete range of power constellations and their effects would obviously exceed the scope of this essay. We will examine only two countries where craft guilds and export-oriented textile trades emerged in a great many cities: England and France.

Compared to many other parts of Europe, England was politically unified and had a strong monarchy relatively early. During the twelfth century, kings and other lords granted special privileges to merchants' guilds, because they regarded delegating specific responsibilities as an efficient means of securing revenues and promoting local regulations. In many of the larger cities, guild officials became politically influential. ${ }^{55}$ As the cities grew larger and more affluent, groups of master artisans were allowed to organize nearly everywhere, albeit subject to the regulations of the commune or the merchants' guild; in many cases they were required to sell their manufactures exclusively to local dealers. ${ }^{56}$ In London, craft guilds eventually managed to operate as political lobbies, due both to the demographic and economic importance of the city and to the complexity of its administration and the rivalries among the merchant elites, which were conducive to changing coalitions. ${ }^{57}$ But since London was a commercial rather than an industrial centre, wholesalers had little difficulty controlling the major guilds. In the provincial towns, organizations of master craftsmen remained both politically and economically subordinate until the end of the fifteenth century, which is why master weavers were often prohibited from engaging in wholesale trade (i.e. exports); in some textile centres they had to join the merchants' guild (which entailed abandoning their occupation), while in others they were allowed to sell their manufactures only to local dealers. ${ }^{58}$

54. See especially Joseph Pérez, La révolution des "Comunidades" de Castille, I 520-1 52 I (Bordeaux, 1970), and Hilario Casado Alfonso, "Guilds, Technical Progress and Economic Development in Preindustrial Spain”, in Paola Massa and Angelo Moioli (eds), Dalla corporazione al mutuo soccorso. Organizzazione e tutela del lavoro tra XVI e XX secolo (Milan, 2004), pp. 309-327.

55. Derek Keene, "English Urban Guilds, c. 900-I 300: The Purposes and Politics of Association", in Ian A. Gadd and Patrick Wallis (eds), Guilds and Association in Europe, 900-1900 (London, 2006), pp. IO-I I (and the literature cited there).

56. By the early thirteenth century, merchants practised this policy of exclusion in many English cities with a substantial concentration of textile workers. See A.B. Hibbert, "The Economic Policies of Towns", in M.M. Postan, E.E. Rich, and Edward Miller (eds), The Cambridge Economic History of Europe, III: Economic Organization and Policies in the Middle Ages (Cambridge, 1963), p. 195.

57. Keene, "Guilds in English Towns", pp. 29, 32-33, 35-37; Pamela Nightingale, "Capitalists, Crafts and Constitutional Change in Late Fourteenth-Century London", Past E Present, I 24 (1989), pp. 3-35; David Nicholas, The Growth of the Medieval City: From Late Antiquity to the Early Fourteenth Century (London [etc.], 1997), pp. I30-I31, I35-I36, 220-22 I, 238-239, $283-284$.

58. Mickwitz, Kartellfunktionen, pp. I40-I46; Hibbert, "Economic Policies", pp. 22 I-222; E.M. Carus-Wilson, Medieval Merchant Venturers (London, 1967), pp. 222-238; J.L. Bolton, The Medieval English Economy, II 50-I500 (London, 1980), p. 32 I. 
By the late fifteenth century, the balance of power had shifted somewhat, and craftsmen were starting to be employed in the higher offices of city government, but the merchants effectively remained in control. Precisely because merchant capital continued to prevail and to determine the basic operating procedures, master weavers often had difficulty adapting to economic changes: they had neither the necessary capital nor the institutional leverage to devise adequate strategies. ${ }^{59}$ And while the sale of monopolies for hard cash by the Crown provided some groups of master artisans with new opportunities in the sixteenth and early seventeenth centuries, no lasting benefits were forthcoming for the guild-based textile trades. After all, the proliferation of monopolies encouraged increasing numbers of merchant entrepreneurs to transfer their operations from the cities to the countryside, where producers rarely had exclusive rights. ${ }^{60}$

Yet the craft guilds in the export-oriented urban trades did not disappear. In the late seventeenth and early eighteenth centuries, textile branches of national significance were revitalized in some incorporated towns. In Exeter, the Weavers', Tuckers' and Shearman's Company, which had obtained a royal charter in 1620 , retained full control over the admission of new members until I793. Periods of stagnation or decline in this textile centre were continuously followed by periods of recovery and growth, demonstrating that the Company adapted to changing circumstances. Was this because an oligarchy of capitalist masters wielded administrative and economic control, as the abundance of complaints from ordinary members suggests? The main point is that not all eighteenth-century craft guilds were relegated to "the scrapheap of anachronistic regulations inhibiting freedom of enterprise and progress in industry". ${ }^{61}$

In many cities, nonetheless, these organizations gradually lost their share in the manufacture of export goods from the second quarter of the eighteenth century onward. In Coventry, guild regulations in silk weaving and worsted weaving were abolished after $1760,{ }^{62}$ and merchant entrepreneurs appear to have controlled the overwhelming majority of London

59. Heather Swanson, Medieval Artisans: An Urban Class in Late Medieval England (Oxford, I989), pp. I $23-125$, I $48-149$.

60. J.H. Baker, An Introduction to English Legal History (London, I995), pp. 5 I I-5 I3. See the comments of Gary Richardson, "Guilds, Laws, and Markets for Manufactured Merchandise in Late-Medieval England”, Explorations in Economic History, 4I (2004), pp. 20-22, who underlines that most corporations purchased monopolies during the Tudor and Stuart dynasties.

61. Michael John Walker, "The Extent of the Guild Control of Trades in England, c.1660-1 820: A Study Based on a Sample of Provincial Towns and London Companies" (Ph.D., University of Cambridge, 1985), pp. 7, I 56-1 58, 242, 388-391 (on p. 390). See also Penelope Corfield, The Impact of English Towns, I700-I 800 (Oxford, I982), pp. 86-94, and Michael Berlin, "Broken all in Pieces: Artisans and the Regulation of Workmanship in Early Modern London", in Geoffrey Crossick (ed.), The Artisan and the European Town, I500-1900 (Aldershot, 1997), pp. 75-91. 62. Walker, "The Extent of the Guild Control", pp. I47-1 50. 
textile producers by that time by means of putting-out systems. ${ }^{63}$ Regardless of how the textile trades were organized, however, throughout the eighteenth century manufacturers in England very often received government protection on their imports of finished goods and exports of raw materials, even when their interests conflicted with those of the merchants and financiers: ${ }^{64}$ a crucial difference from the United Provinces.

In late medieval France the power constellation was far more complex than in England, giving master artisans who wanted to organize some leverage. The Crown faced powerful groups of regional aristocrats and greatly needed the support of the cities, but at the same time had to consider opposing groups within the cities, where power was concentrated among a small elite consisting primarily of merchants. The expansion of the state coincided on the one hand with the political emancipation of the cities (which in most cases were allowed to elect their own aldermen) and on the other hand with the rise of a municipal noblesse de robe, a nobility of the robe, which progressively tightened its control over the city and town councils. ${ }^{65}$ Many groups of master artisans took advantage of this fundamental change and directly requested the Crown for permission to form a guild and become fully autonomous in "police matters". Since the French king welcomed new corporative organizations as additional sources of income, he nearly always admitted them and continued this practice in the sixteenth century; the great ordinances of I 58 I and I 597 extended the corporative regime throughout the kingdom and placed it under the exclusive supervision of the state. ${ }^{66}$

The system of requiring master artisans to present the statutes of their organizations directly to the Crown and having them pay to have these statutes approved offered the advantage that industrial interests generally prevailed. This was essential in a country where many cities were firstrate textile manufacturing centres by the fourteenth century - heavily concentrated in northern France and in the Languedoc region - and explains why master artisans involved in urban export trades tended to be

63. L.D. Schwarz, London in the Age of Industrialisation: Entrepreneurs, Labour Force and Living Conditions, I700-I850 (Cambridge, I992), pp. 2 I0-2 I 2.

64. Tim Keirn, "Parliament, Legislation and the Regulation of English Textile Industries, I689-17r", in Lee Davison et al. (eds), Stilling the Grumbling Hive: The Response to Social and Economic Problems in England, I689-1750 (Stroud, I992), pp. I-24; Martin J. Daunton, Progress and Poverty: An Economic and Social History of Britain, I700-1850 (Oxford, 1995), pp. 543-545.

65. Bernard Chevalier, Les bonnes villes de France du XIVe au XVIe siècle (Paris, I982), pp. 74, I 29-I 30, I 33, I 35-I 4 I, I 43-I 49. See also Wim P. Blockmans, "Voracious States and Obstructing Cities: An Aspect of State Formation in Preindustrial Europe", in Charles Tilly and Wim P. Blockmans (eds), Cities and the Rise of States in Europe, AD I000 to I 800 (Boulder, CO [etc.], I989), pp. $235-236$.

66. Emile Coornaert, Les corporations en France avant 1789 (Paris, I968), pp. I29-I 34. 
allowed to sell their manufactures directly and to act as contractors. In the early sixteenth century wealthy master silk weavers in Tours formed extensive subcontracting networks, which in addition to poorer colleagues included silk throwers and warpers, while in Amiens master serge weavers applied subcontracting so systematically that according to a contemporary most producers were left destitute. ${ }^{67}$

Were both cities representative cases? Despite the wealth of studies about urban textile trades in late medieval and early modern France, no answer is available to this question: data on the actual organization of production are hardly ever provided. This is obviously a serious handicap, since while the official regulations stipulated what was prohibited or allowed, they do not necessarily reflect what happened in practice. In the guild-based cloth industry in fifteenth-century Rouen, for example, no restrictions existed concerning the number of journeymen a master could employ or the number of looms in a workshop. Nor were master artisans prohibited from using subcontracting. Still, the normative and narrative sources suggest that no concentration whatsoever existed. ${ }^{68}$ But was that indeed the case? Or do the sources obscure the reality? ${ }^{69}$

The situation is all the more puzzling, because we cannot assume that everything remained the same during the early modern period. With respect to the eighteenth century, we know that the relative positions of merchants and master artisans could change dramatically in some textile centres. In Amiens négociants (wholesalers) managed after intensive lobbying to convince the authorities to prohibit master serge weavers from trading independently, as they did in the guild-based silk industry in Lyons as well. ${ }^{70}$ Basically, urban textile trades in France were organized in many different ways. Determining which system predominated where and when - not to mention why - is impossible at this time.

67. Edouard Maugis, "La saieterie à Amiens, I480-1587", Vierteljabrschrift für Sozial- und Wirtschaftsgeschichte, 5 (1907), pp. I-I I 5; Bernard Chevalier, Tours, ville royale (1356-I520). Origine et développement d'une capitale à la fin du Moyen Age (Louvain [etc.], 1975).

68. Jean-Louis Roche, "De la nature du drapier médiéval. L'exemple rouennais", Revue Historique, 302 (2000), pp. 3-3 I.

69. Jean-Pierre Sosson, "Les métiers: norme et réalité. L'exemple des anciens Pays-Bas méridionaux aux XIVe et XVe siècles", in Jacqueline Hamesse and Colette Muraille-Samaran (eds), Le travail an Moyen Age. Une approche interdisciplinaire (Louvain-la-Neuve, 1990), pp. 339-348.

70. On Amiens: Pierre Deyon, Amiens, capitale provincial; Étude sur la société urbaine an XVIIe siècle (Paris [etc.], 1967), pp. 226-227, 23 I-233. On Lyons: Justin Godart, L'ouvrier en soie: monographie du tisseur lyonnais. Etude historique, économique et sociale. Première partie: la réglementation du travail, I466-I79I (Lyons, I899), pp. 30I-323, and Maurice Garden, Lyon et les Lyonnais an XVIIIe siècle (Paris, I970), pp. 275-285, 307-309, 572-592. Serious clashes occurred between wholesalers and textile manufacturers in other French cities as well during the eighteenth century. See for instance F. Dornic, L'industrie textile dans le Maine et ses débouchés internationaux (Le Mans, 1955), pp. 14-16. 


\section{CONCLUDING REMARKS}

Far more empirical research is needed to determine in what measure master artisans manufacturing export goods, especially textiles, had actual economic leverage enabling them to launch entrepreneurial initiatives in late medieval and early modern Europe. The studies available nonetheless reveal a few general patterns.

First, institutional contexts where producers established and enforced the regulations differed from those in which merchants wielded considerable direct or indirect control. In the former case industrial interests prevailed, while in the latter case commercial ones did. Merchants did not ordinarily oppose setting up formal craft guilds, provided that these organizations served their purposes. Restricting commercial competition was a constant concern of all those who traded export goods, and this is precisely what wholesalers have attempted to do from the thirteenth century onward, especially in cities with export-oriented trades. ${ }^{71}$ Such a policy of exclusion also meant subjecting producers to rules that made obtaining a market share impossible or at least extremely difficult. The most effective strategy was to prohibit master artisans from selling their manufactures directly, while the second-best strategy was to support all actions conducive to imposing and maintaining corporative restrictions on business size; merchants would act as "protectors" of the small masters in such cases. ${ }^{72}$ Wherever merchants achieved their objectives, master artisans in export-oriented textile trades would by definition lack the leverage to adapt to economic changes, let alone to bring about such changes themselves. In such contexts, asking whether craft guilds were economically "efficient" institutions is pointless.

Second, political, institutional, and socio-economic changes were closely related. While craft guilds were formed at the initiative of the producers nearly everywhere, the contexts varied considerably, and these differences determined in large measure the regulations included in or, conversely, omitted from the charters granted by public authorities. The power constellation in which guilds were formed was crucial. All data suggest that organizations of textile producers serving export markets during the late Middle Ages became politically and economically autonomous only when different power groups with divergent or even opposing interests existed, enabling producers to form coalitions. In such contexts "powerful craft guilds" did indeed emerge - powerful in that they were able to act as political lobbies and to defend their industrial interests.

71. See the pertinent remarks of Hibbert, "Economic Policies", pp. 194, 200-205.

72. In this connection, see the interesting remarks of Gail Bossenga, "Protecting Merchants: Guilds and Commercial Capitalism in Eighteenth-Century France", French Historical Studies, Is (1988), pp. 693-703, and idem, The Politics of Privilege: Old Regime and Revolution in Lille (Cambridge, I991), pp. I46-I 49. 
Third, members of "powerful craft guilds" were nearly always entitled to trade and to use subcontracting, although statutes rarely provided explicitly for such freedom (also very revealing). The combination of these two elements allowed wealthy members to expand their scale and accumulate capital, thus becoming capitalist entrepreneurs. Several indications suggest that the presence of these master artisans facilitated product innovation in guild-based textile trades: since they were key operators in economic and institutional respects, they had little difficulty introducing a new product and manufacturing large quantities by means of subcontracting. ${ }^{73}$

Fourth, the economic significance of "powerful craft guilds" needs to be placed in perspective. The available data suggest that there were more regions where guild-based textile trades were dominated by putting-out merchants than where master artisans were able to take major economic decisions. The variations are largely attributable to the political balances of power at the time these craft guilds were established, as was noted above, although dramatic changes in these balances of power over the centuries could have a great impact on the organization of production, as the examples from Amiens and Lyons demonstrate. Moreover, the existence of "powerful craft guilds" was not a necessary or sufficient condition for achieving industrial growth, as the English case indicates. The economic "efficiency" of such institutions derives essentially from their ability in several European cities and even regions to prevent the logic of merchant capital from being the sole factor determining the development of the textile trades prior to the Industrial Revolution. 